CITY AND STATE IN THE MEDIEVAL LOW COUNTRIES 
SEUH

STUDIES IN EUROPEAN URBAN HISTORY (1100-1800)

VOLUME 52

Series Editors

Marc Boone

Anne-Laure Van Bruaene

Ghent University 


\section{City and State in the Medieval Low Countries}

Collected studies by Marc Boone

Collected, edited and introduced by his students JONAS BRAEKEVELT, FREDERIK BUYLAERT, JAN DUMOLYN, JELLE HAEMERS, SARAH KEYMEULEN, BART LAMBERT, ELODIE LECUPPRE-DESJARDIN, HANNES LOWAGIE, MILAN PAJIC, KRISTOF PAPIN, ANNE-LAURE VAN BRUAENE, TINEKE VAN GASSEN, BRAM VANNIEUWENHUYZE

with the technical assistance of

NIELS FIEREMANS

and with translations by

DUNCAN BROWN AND LEE PREEDY

BREPOLS 
Cover image: detail of the Ghent Altarpiece, (C) Art in Flanders // Sint-Baafskathedraal Gent, www.artinflanders.be, foto Dominique Provost Back cover photograph: Marc Boone in his study, (C) Stefaan Temmerman
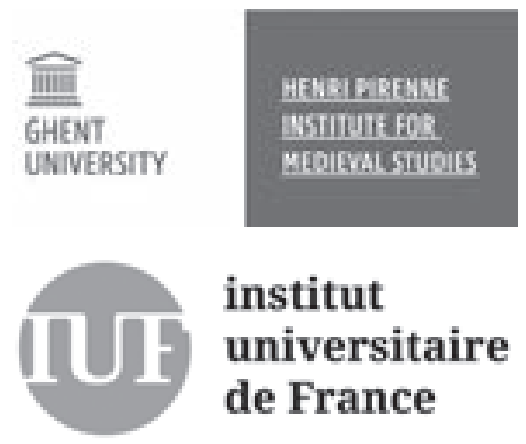

Research Alliance Urban
History UGent-VUB

(C) 2021, Brepols Publishers n.v., Turnhout, Belgium.

All rights reserved. No part of this publication may be reproduced, stored in a retrieval system, or transmitted, in any form or by any means, electronic, mechanical, photocopying, recording, or otherwise without the prior permission of the publisher.

$\mathrm{D} / 2021 / 0095 / 208$ ISBN 978-2-503-58123-1 E-ISBN 978-2-503-58124-8 DOI 10.1484/M.SEUH-EB.5.115908

ISSN 1780-3241

E-ISSN 2294-8368

Printed in the EU on acid-free paper. 